\title{
Effectiveness of Laser Acupuncture and Battlefield Acupuncture Therapy for Pain Management in Juvenile Idiopathic Arthritis : A Case Report
}

\author{
Dwi Surya Supriyana ${ }^{1}$, Arsita Eka Prasetyawati², Robby G. Sebayang ${ }^{1}$, Kemas \\ Abdurrohim ${ }^{1}$ \\ 1. Medical Acupuncture Department, Dr. Cipto Mangunkusumo Hospital, Central Jakarta, \\ Indonesia \\ 2.Department of Public Health and Prevention Medicine, Faculty of Medicine, \\ Universitas Sebelas Maret, Surakarta, Indonesia
}

Corresponding author : 82dwisurya@gmail.com

\begin{abstract}
Introduction : Juvenile Idiopathic Arthritis (JIA) is a comprehensive chronic condition of a joint inflammatory autoimmune process, resulting a decrease of function in a long period characterized by fever and pain, which is include all form of unknown etiology that begin before 16 years old. Here we reported effectiveness of Laser Acupuncture and Battlefield Acupuncture Therapy for pain management in JIA case.

Case report: A 10-year-old girl diagnosed with JIA was admitted to the pediatric department in Dr. Cipto Mangunkusumo Hospital, and treated by clinical multidisiplinary team from pediatrict, orthopedist, nutritionist, physiotherapist, and medical acupuncture doctor. She was referred to the Medical Acupuncture Department due to complaining of prolonged continous pain throughout her joints, and swelling in her right knee joint. The patient received laser acupuncture therapy in acupoints LI4 Hegu, LI11 Quchi, ST36 Zusanli, SP9 Yinliquan, and EX-LE5 Xiyan. Battlefield Acupuncture Points method (ears) of Omega2, Shenmen, Gyrus Cingulate, Thalamus, and Point Zero. The Therapy was given every day for two weeks and showed a significant improvement on patient's Visual Analog Score.

Conclusion : The combination regimen was effective in relieving pain and swelling, and caused a significant Visual Analog Score and Range of Motion improvement in our case.
\end{abstract}

Keywords : juvenile idiopathic arthritis, laser acupuncture, battlefieldacupuncture

\begin{abstract}
ABSTRAK
Pendahuluan : Juvenile Idiopathic Arthritis (JIA) adalah suatu kondisi kronis komprehensif dari proses inflamasi autoimun pada persendian, yang menyebabkan penurunan fungsi dalam periode waktu yang lama dan dikarakteristikkan adanya demam dan nyeri, dengan etiologi yang tidak diketahui serta dimulai pada usia kurang dari 16 tahun. Di sini, kami melaporkan efektivitas dari terapi laser akupunktur dan akupunktur Battlefield untuk manajemen nyeri pada kasus JIA.

Laporan kasus : seorang anak perempuan usia 10 tahun didiagnosis dengan JIA di departemen pediatri RS Dr. Cipto Mangunkusumo dan dirawat oleh tim multidisipliner terdiri dari dokter spesialis anak, ortopedi, ahli gizi, fisioterapi, dan dokter spesialis akupunktur medik. Dia dirujuk ke departemen Akupunktur Medik karena mengeluhkan nyeri yang berkepanjangan dan terus-menerus pada seluruh persendiannya, serta bengkak pada sendi lutut kanan. Pasien mendapatkan terapi laser akupunktur di titik akupunktur LI4 Hegu, LI11 Quchi, ST36 Zusanli, SP9 Yinliquan, and EX-LE5 Xiyan. Metode Battlefield (aurikulo akupunktur) dilakukan pada titik Omega2, Shenmen, Gyrus Cingulate, Thalamus, and Point
\end{abstract}


Zero. Terapi diberikan setiap hari selama 2 minggu dan menunjukkan perbaikan signifikan pada Visual Analog Score pasien.

Kesimpulan : kombinasi terapi pada kasus ini efektif untuk mengurangi nyeri dan bengkak, dan menunjukkan perbaikan yang signifikan dari Visual Analog Score dan Range of Motion.

\section{Kata kunci : juvenile idiopathic arthritis, akupunktur laser, akupunktur battlefield}

\section{INTRODUCTION}

Juvenile Idiopathic Arthritis (JIA) is the most common chronic rheumatic disease in childhood $^{1,2}$. A comprehensive condition of a joint inflammatory autoimmune process, which included all form of uncertain etiology with onset below 16 years $\mathrm{old}^{1-3}$. This abnormality is divided into several subtypes according to demographic characteristics, clinical appearances, treatment modalities, and disease prognosis that resulting in decrease of function within a long period ${ }^{1,3}$.

JIA reported the incidence rate approximately 2 to 23 per 100,000 personyears and the prevalence varies between 4 to 400 per $100,000^{4}$. The disparity in the frequency of its subtypes has been noticed in different geographical areas or ethnic populations. Environment and genetic affect chategories of JIA ${ }^{3-4}$. In Western Countries, oligoarthritis is the most common subtypes ${ }^{3-4}$, while systemic arthritis is greatly in $\mathrm{Asia}^{4}$. Though diagnosis of JIA frequently occurs in females ${ }^{1-5}$.

Chou and Chu (2017) reviewed 43 studies in systematic review and concluded that acupuncture alone or combined with other treatment modalities is beneficial to the clinical conditions of RA without adverse effects reported and can improve function and quality of life and is worth trying. Several important possible mechanisms were summarized including anti inflammatory effect, anti oxidative effect, and regulation of immune system function ${ }^{11}$.
Harjacek et al (2008) reported biostimulating Low-level Laser Therapy (LLLT) is a valuable addition the standard treatment modalities currently used for pain and inflammation treatment of enthesitis in children with juvenile spondyloarthropathy ${ }^{12}$. Based on existing references showed laserpuncture is beneficial for rhematoid arthritis, so we gave this combined therapies for this case.

\section{CASE REPORT}

A 10-year-old girl complained of pain throughout her joints. The main complaint was prolonged continuous fever accompanied by joint pain in right knee joint region. Anamnesis, physical examination, and adjunctive examination results showed that the patient was diagnosed with JIA. The patient was admitted to the pediatric department of Dr. Cipto Mangunkusumo Hospital and was treated by clinical multidisiplinary team from pediatrict, orthopedist, nutritionist, physiatrist and physiotherapist, and medical acupuncture specialist.

The patient was consulted to Medical Acupunture Department due to her pain in both of her joints, especially right knee joint region. Previously, the patient was given morphine which caused her to have constipation. Pain on motion in both knee were noted at the first our examination therefore difficult to assessed the Range of Motion (ROM). 


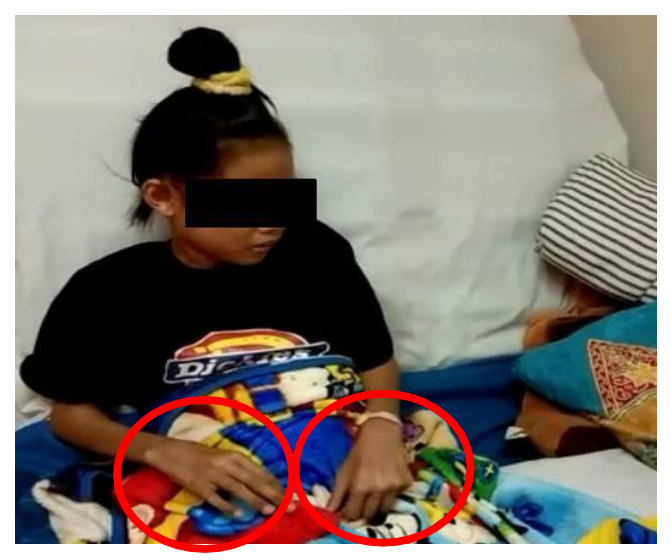

(a)

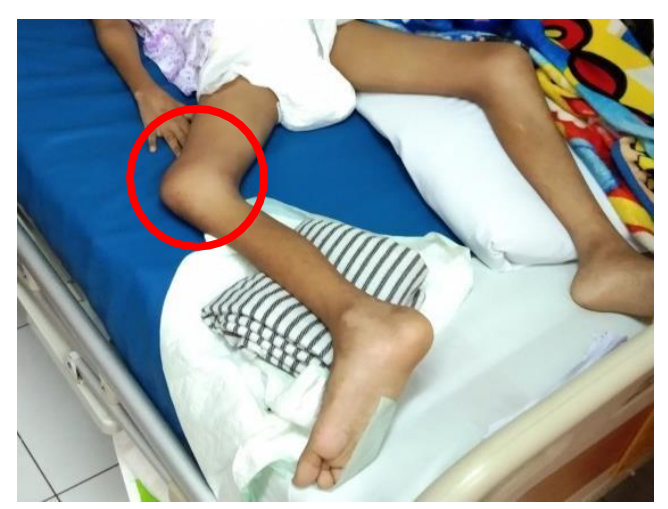

(b)

Figure 1. Patient JIA with joint pain and right knee joint swelling. (a) location of the pain joint upper extremity (b) location of the swelling and pain joint lower extremity

The patient received combination of two acupuncture modalities : Laser Acupuncture Therapy and Auriculo Acupuncture Therapy with Battlefield method. Laser Acupuncture Therapy using Laser Pen Rj type 130, P max: 50 $\mathrm{mV}, 785 \mathrm{~nm}$ laser apuncture 2 joule, Nogier

A. Acupuncture points were LI4 Hegu, LI11 Quchi, ST36 Zusanli, SP9 Yinlinquan, and EX-LE5 Xiyan. Manual acupuncture with Battlefield Acupuncture Points Method (ears) on Omega2, Shenmen, Gyrus Cingulate, Thalamus, and Point Zero was performed using Huanqiu acupuncture needle with $0.18 \times 7 \mathrm{~mm}$. Both therapies were given twenty minutes every day for two weeks.

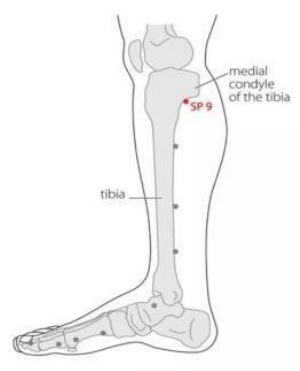

SP9

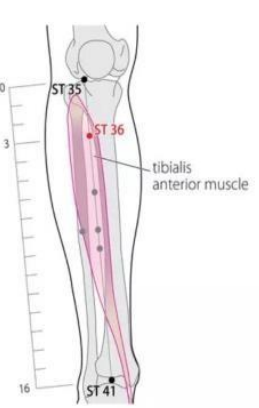

ST36

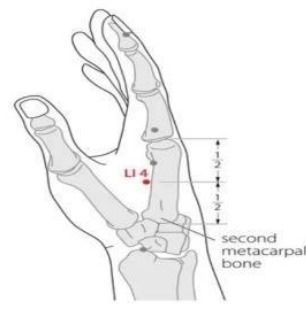

LI4

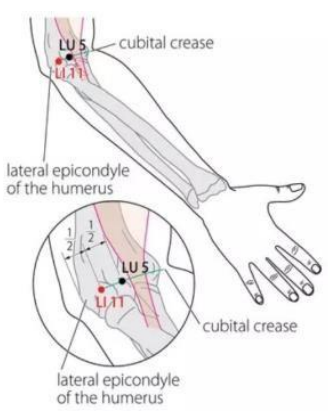

LI11
Figure 2. locations of the acupoints in a 10-year-old-girl with $\mathrm{JIA}^{5}$.

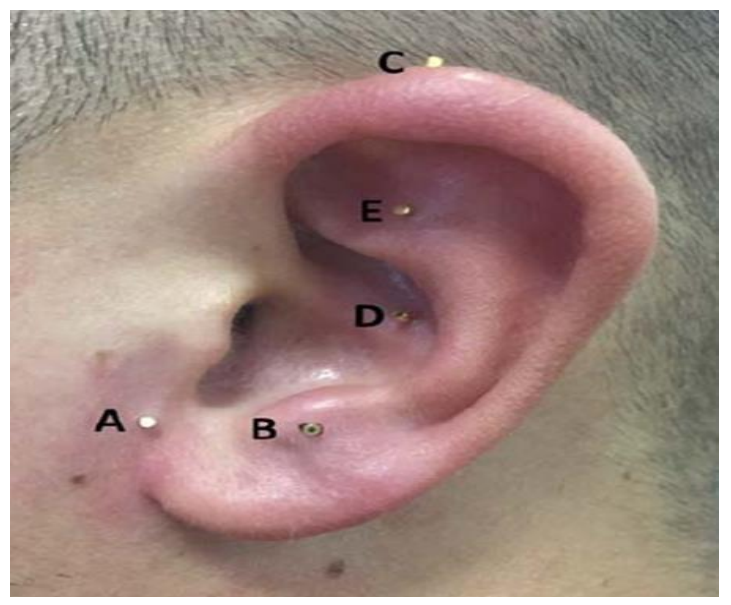

Figure 3. Battlefield Acupuncture Protocol : (A) Cyngulate gyrus, (B) Thalamus, (C) Omega2, (D) Poin zero, (E) Shen Men'. 


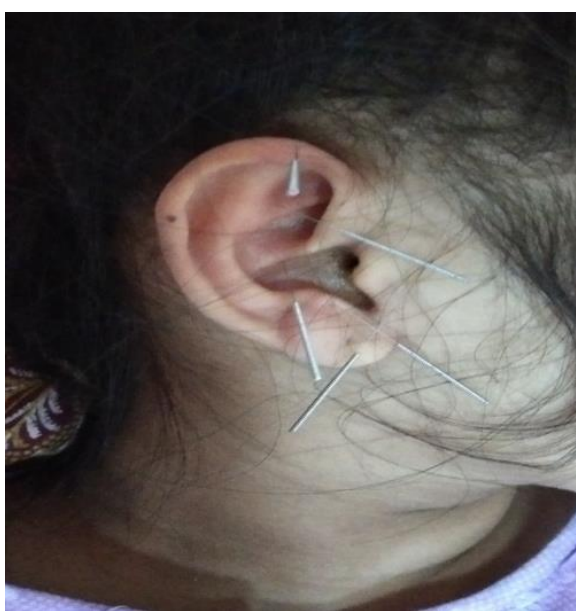

Figure 4. locations of the Battlefield Acupuncture Points in patient.

Evaluation of the signs and symptoms be preffered assess pain using the Visual Analog Scale (VAS) showed significant improvement throughout therapy. The VAS score before and after treatment from 4 to 2 indicated significant decreased pain. Full extension was observed for both knee but flexion was limited to $130^{\circ}$.

\section{DISCUSSION}

JIA is the most commonly found arthritis disease in children ${ }^{1}$. Diagnosis of JIA is obtained through clinical criteria. Diagnosing disease definitively needs time because of hidden symptoms. There is no specific laboratory examination for JIA, thus mistakes can occur while detecting the working diagnosis of this disease. The result of laboratory examination is useful for determining working diagnosis from several differential diagnosis and determining the subtype of disease. Diagnosis determination of JIA uses exclusion criteria which considers full clinical evaluation, including personal and family history of the patient and current pathological incidences, and special consideration to pain and morning stiffness $^{4,7}$.

Detailed physical examination should be performed, especially around joints area, both during initial and further examinations. VAS is an important examination that should be determined during every visit ${ }^{8}$. Radiographs are still the gold standard to detect damage in joint structure and growth and maturity from bone abnormalities in JIA patients. However, low sensitivity of simple radiographic images in identifying active synovitis and limitation in observing erosion changes in the beginning of disease requires more advanced additional radiographic examination ${ }^{2,8}$.

Besides determining diagnosis, other thing that should be performed is follow up JIA patients to examine the activity of the disease ${ }^{6}$. There are various assessment indicators that are often used to assess disease activity (VAS by the patient or their parents, VAS by the examining doctor, the number of joints involved, anemia, platelet count, Steinbrocker score), however none of them can assess accurately ${ }^{8,9}$.

JIA management is the most importance, especially to reduce the possibility of disability due to joint deformity. It is performed using the approach through multidisciplinary team, especially rheumatology pediatric. The purpose of JIA management is to control disease and limit the disability of the patient by balancing the use of strong immunosuppressant and adverse effect of the medication ${ }^{10}$.

Latest development has created revolution for JIA medication, i.e. a more selective biological therapy to block specific target from inflammatory pathway ${ }^{1,2,7,10}$. Biological therapy is not only used for refractory JIA, but also became the first choice of treatment for certain subtypes of JIA ${ }^{10}$. The instruments that recommended by the Association of American Rheumatologist to assess disease activity or JIA development that is often used are Childhood Health Assessment Questionnaire (CHAQ) and Juvenile Arthritis Disease Activity Score (JADAS) 1,3,4,7-9.

Acupuncture has become one of the minimally invasive therapeutic for the treatment of this case. Several acupunctures studies relevant to this case include systematic 
review by Chou and Chu (2018) which aimed to investigate in detail available scientific information regarding the clinical potency of acupuncture in rheumatoid arthritis (RA) and to reveal the mechanism suggested. Forty-three studies were obtained from electronic database search from 1974 to 2018 . The conclusion was obtained acupuncture alone or combination of acupuncture with other therapy modalities had advantages in clinical condition of rheumatoid arthritis without harmful adverse effects and could improve quality of life. The mechanism was based on include inflammatory effect, antioxidative effect, and immune system function regulation ${ }^{11}$.

There was an investigation about the value of Low-Level Laser Therapy (LLLT) on enthesitis in 20 children with juvenile spondyloarthropathies $\quad(\text { JsIA })^{12}$. The intervention was given NSAID administration with the addition of LLLT. VAS was performed after a month of therapy. The result showed a significant decrease in mean VAS value of the patient $^{12}$.

In this case, the acupuncture points used for anti-inflammatory mechanism during treatment were LI4, LI11, and ST36. These points have been proven good for antiinflammatory mechanism by EBM. JIA case is an autoimmune disorder which has been described previously. Joint damage was caused by macrophage activation and increased production of TNF, IFN, and IL-2 which have harmful effect to the synovial ${ }^{7,13}$.

Acupuncture role in inflammation include suppressing anti-inflammatories such as TNF, IFN, and IL-22, and macrophages through fast pathway by involving afferent nerve fibers of the vagus nerve to viscerosensory nucleus of the solitary tract in the brainstem and slower path which involved cytokine derived from choroid plexus and circumventricular organ. The direct effect of sympathetic vagus nerve through neuroimmune interaction or indirect effect through neuroendocrine adrenal axis. The bond between catecholamine flow to adrenergic $\beta 2$ receptor decrease proinflammatory such as TNF, IL-1 $\beta$, IL-6, and IL-18 and an increase in anti-inflammatory such as IL-10. The signal is also relayed to the hypothalamus and the dorsal vagal complex to stimulate the release of $\mathrm{ACTH}$, thereby activating the humoral antiinflammatory pathway. In the other hand, macrophage that bond with acetylcholine in $\alpha 7$ nicotinic acetylcholine receptor will inhibit the production of proinflammatory cytokines, such as TNF- $\alpha^{14,15}$.

There are some explanation working mechanism of acupuncture on immnune response ${ }^{16}$. The first way was through humoral pathway with macrophage as target, in inflammatory area and other extensive area in the brain, releasing anti-inflammatory cytokines and hormones reacting to macrophage as inflammatory cytokine suppressor and had advantageous effect in other parts of the brain, such as $\beta$ endorphin. The second way was through the nerve pathway, either through sympathetic or parasympathetic by releasing noradrenergic and acetylcholine. The last pathway is neural and coupled directly from the periventricular nuclei and the arcuate nucleus of the hypothalamus to the periaquaductal gray (PAG), and then to the raphe nuclei and to the dorsal horn of the spinal cord. The inhibition action occurs produced or released antiinflammatory mediators such as IL-10, norepinephrine, serotonin, glucocorticoid, acetylcholine, and $\beta$ endorphin ${ }^{16}$.

Laser was used to stimulate the patient she was stilling a child and might not be comfort with needling. The patient just wants to be needling in her ears for Battlefield Acupuncture therapy.. G. Litscher and G. Opitz assessed the effect of laser puncture to the speed of ophthalmic blood flow, which had acupuncture effect of more than $1.3 \mathrm{~W} / \mathrm{cm}^{2}$. The density with higher power than $5 \mathrm{~W} / \mathrm{cm}^{2}$ can be equated with stimulation from acupuncture needle ${ }^{17}$. 
LLLT mechanism acts in suppressing inflammation and as analgesic. Several mechanisms available include LLLT antiinflammatory mechanism by suppressing inflammatory mediators, such as prostaglandin $\left(\mathrm{PGE}_{2}\right)$, thromboxane (TXA2), leukotrienes (LTD4), nitric oxide (NO), cyclooxygenase (COX), TNF- $\alpha$. Suppressed inflammatory mediators will suppress vasodilation and reduce intravascular permeability, thus the exudates from joint tissue or in synovial fluid will decrease and the volume and composition of synovial fluid can be maintained as normal as possible. In arthritis patients, there are some changes in composition and the amount of synovial fluid, especially the number of chondrocytes and synoviocytes ${ }^{18,19}$.

LLLT mechanism as analgesic in arthritis consists of several mechanisms. LLLT has a biostimulation effect by increasing proliferation and migration, especially of fibroblasts. LLLT can also modulate cytokines, growth factors, and inflammatory mediators, thus increasing tissue oxygenation. The other mechanism includes release of opioid through immune cells migration by releasing local $\beta$ endorphin. Laser acupuncture can also increase the activity of Na-K pump, thus increasing the pain threshold caused by stimulation of sensory nerve cells ${ }^{18,20}$.

This patient received Battlefield Ear Acupuncture, which is one of ear acupuncture therapy approaches to resolve pain, both acute and chronic. Battlefield acupuncture was firstly used to reduce pain in military forces, both active and veteran because it can help in reducing the use of morphine and help military on duty to remain active without the use of medication $^{18,21}$.

The mechanism of ear acupuncture in giving analgesic effect is through the activation of several areas of pain matrices. Pain matrices are the area in the brain which are thought to be involved in anticipating pain, analgesic and placebo condition. These pain matrices consist of somatosensory and association cortex (SI and SII), insula, thalamus, amygdala, hippocampus, and cingulate cortex and PAG. These areas are activated by opioid and work together in the process of nociceptive modulation and give the experience of pain ${ }^{22}$.

Ear acupuncture is known to increase the level of endorphin and encephalin in blood serum and cerebrospinal fluid. Peptide opioid such as beta endorphin, encephalin and dynorphin along with their receptors are spread extensively at the end of the primary afferent and various areas in the central nervous system which are associated with pain nociceptive. Opioid peptide and its receptors such as $\mu, \delta$ and $\kappa$ are often found in the nucleus raphe magnus and nucleus submedius caudatus, which are the parts of the brain which create descendent inhibition system ${ }^{22}$.

\section{CONCLUSION}

The combination regimen was effective in relieving pain, swelling, and caused a significant Visual Analog Score improvement with minimal side effects for children. Further investigations are required regarding acupoint selection and therapeutic doses to improve the effectiveness and efficacy of therapy and fully elucidate the mechanism of action of the acupuncture modality.

\section{REFERENCES}

1. Barut K, Adrovic A, Şahin S, Kasapçopur Ö. Juvenile idiopathic arthritis. Balkan Med J 2017;34(2):90-101.

2. Giancane G, Consolaro A, Lanni S, Davì S, et al. Juvenile idiopathic arthritis: diagnosis and treatment. Rheumatol Ther 2016;3(2):187207.

3. Jane Munro, et al. Clinical guideline for the diagnosis and management of juvenile idiopathic arthritis; 2009.

4. Kim YD, Job A V, Cho W. Differential diagnosis of juvenile idiopathic arthritis. Journal of Rheumatic Diseases 2017;24(3):131- 137

5. World Health Organization. WHO Standard Acupuncture Point Locations. WHO.

6. Fox, L., Murakami, M., Danesh, H., Manini, 
AF. American journal of emergency medicine Battlefield acupuncture to treat low back pain in the emergency department. Am. J. Emerg. Med., [internet] 2018; 36(6):1045-8.

7. Huang J-L. New advances in juvenile idiopathic arthritis. Chang Gung Med J. 2011;35:1-14.

8. Hahn Y-S, Kim J-G. Pathogenesis and clinical manifestations of juvenile rheumatoid arthritis. Korean J Pediatr. 2010;53(11):921.

9. Mellins ED, MacAubas C, Grom AA. Pathogenesis of systemic juvenile idiopathic arthritis: Some answers, more questions. Nat Rev Rheumatol 2011;7(7):416-426.

10. Kasapcopur O, Barut K. Treatment in juvenile rheumatoid arthritis and new treatment options. Türk Pediatr Arşivi 2015;50(1):1-10.

11. Chou P-C, Chu H-Y. Clinical efficacy of acupuncture on rheumatoid arthritis and associated mechanisms: a systemic review. Evidence-Based Complement Altern Med 2018;1-21.

12. Harjacek M, Kelava T, Lamot L. The therapeutic value of low-energy laser (LLLT) for enthesitis in children with juvenile spondyloarthropathies. Pediatr Rheumatol 2008;6(Suppl 1):P64.

13. Hashkes PJ, Laxer RM, Hashkes PJ LRM. Update on the medical treatment of juvenile idiopathic arthritis. Curr Rheumatol Rep 2006;8(6):450-458.

14. Kavoussi B, Ross BE. The neuroimmune basis of anti-inflammatory acupuncture. Integr Cancer Ther 2007;6(3):251-257.

15. Zijlstra FJ, Van Den Berg-De Lange I, Huygen FJPM, Klein J. Anti-inflammatory actions of acupuncture. Mediators

Inflamm 2003;12(2):59-69.

16. Cho ZH, Hwang SC, Wong EK, et al. Neural substrates, experimental evidences and functional hypothesis of acupuncture mechanisms. Acta Neurol Scand 2006;113(6):370-377.

17. Litscher G, Opitz G. Technical parameters for laser acupuncture to elicit peripheral and central effects: State-of-the-art and short guidelines based on results from the Medical University of Graz, the German Academy of Acupuncture, and the scientific literature. Evidence-based Complement Altern Med. 2012.

18. Brosseau L, Robinson V, Wells G, et al. Low level laser therapy (Classes I, II and III) for treating rheumatoid arthritis. Cochrane Database Syst Rev 2005;(4):CD002049.

19. Alves ACA, De Carvalho PDTC, Parente M, et al. Low-level laser therapy in different stages of rheumatoid arthritis: A histological study. Lasers Med Sci. 2013;28(2):529-536.

20. Helianthi DR, Simadibrata C, Srilestari A,
Wahyudi ER, Hidayat R. Pain reduction after laser acupuncture treatment in geriatric patients with knee osteoarthritis: a randomized controlled trial. Acta Med Indones-J Intern Med. 2016;48(2):114-121.

21. Pickett H. Battlefield acupuncture. J Chinese Med. 2011;19(96):14-17.

22. Romoli M, Allais G, Airola G, et al. Ear acupuncture and fMRI: A pilot study for assessing the specificity of auricular points. Neurol Sci. 2014;35(suppl. 1):189-193. 